\title{
Factors influencing MOW deinking: Laboratory scale studies
}

\author{
H. Pala, M. Mota, F.M. Gama* \\ Centro de Engenharia Biológica, Universidade do Minho, Largo do Paço, 4719 Braga Codex, Portugal
}

Received 19 January 2004; accepted 18 April 2005

\begin{abstract}
The deinking of MOW is examined at laboratorial scale. The effect of deinking aids, pre-washing and mixing are studied. The operating conditions during pulp treatment affect the pulp and paper properties, interfering with the mechanism of ink removal and modifying the ink particle characteristics. Pre-washing the pulp facilitates the deinking process. Cellulolytic enzymes and deinking chemicals are comparable in terms of ink removal ability.
\end{abstract}

(C) 2005 Elsevier Inc. All rights reserved.

Keywords: Paper pulps; Non-impact inks; Deinking; Enzymes; Image analysis; MOW

\section{Introduction}

The use of recycled fibres for paper manufacture is highly desirable. However, the production of a good quality paper requires an adequate modification of the secondary fibre properties and the removal of a large amount of contaminants, namely stickies, sizing and coating agents, mineral fillers and inks. The selection of equipments and recycling techniques is a difficult task that greatly depends on the type of furnish available for production, thus leading to new research in the recycling field. One of the factors that should be considered is the ink formulation [1], which rends the deinking process particularly difficult, due to the constant modification of its chemical composition.

Generally, the industrial process for removing wastepaper contaminants involves re-pulping, screening, cleaning, washing and flotation [2,3]. Attempting to reflect the industrial process, the laboratory deinking trials frequently include four sequential stages, namely sample preparation, pre-washing, pulp treatment and fibre/ink particles separation. Each stage contributes to the overall effectiveness of deinking. Two goals are envisaged: (i) the detachment of the ink particles from the fibre surface; (ii) the removal or separation of the ink particles.

\footnotetext{
* Corresponding author. Tel.: +351253 604400; fax: +351253678986.

E-mail address: fmgama@deb.uminho.pt (F.M. Gama).
}

In order to favour deinking, chemical products have been used for a long time [1]. More recently, enzymes appeared as an alternative deinking aid [4]. Enzymatic deinking is advantageous for industrial usage because it is efficient, quick and has a low environmental impact [2-7]. However, due to the high heterogeneity of the paper provisions, the behaviour of a particular paper sample during recycling remains to large extent unpredictable. More data are required, to help understanding the action mechanism and the development of an economic and effective process.

In the present work, mixed office wastepaper (MOW) deinking is studied at laboratory scale; the effect of $\mathrm{pH}$, deinking aids, pre-washing and mixing on the deinking process is examined. The office grades are generally more difficult to deink because, during printing, the thermoplastic synthetic polymers present in the laser and photocopy toners fuse at high temperature and adhere strongly to the fibres surface [8-10]. The high-quality fibres content in this paper, however, justifies its re-utilisation.

\section{Methods and materials}

The office wastepaper samples were treated according to the general protocol presented in Fig. 1. The experimental plan was organized in order to analyse: (i) the effect of the deinking aids (chemical products and/or enzymes) on pulp 


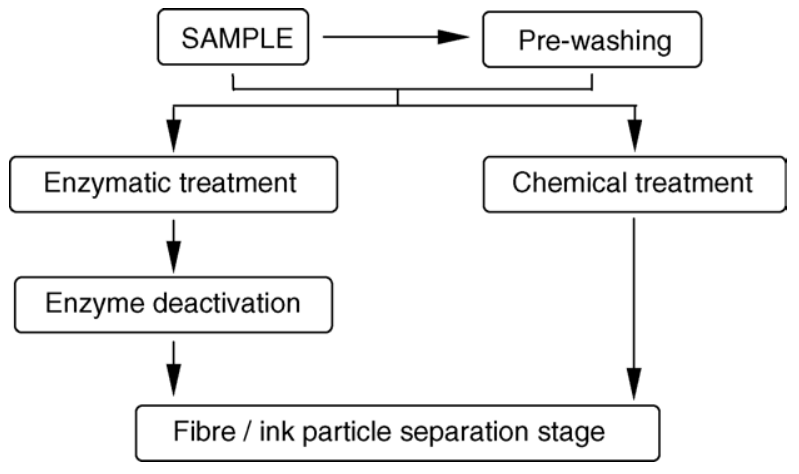

Fig. 1. General deinking sequence.

Table 1

Enzyme characterisation and dosages applied to the pulps

\begin{tabular}{lllcc}
\hline Enzyme & FPase & & CMCase & Xylanase \\
\cline { 2 - 5 } & FPU $(\mathrm{ml})^{\mathrm{a}}$ & FPU $(\mathrm{g})^{\mathrm{b}}$ & $\mathrm{U}(\mathrm{ml})^{\mathrm{a}}$ & $\mathrm{U}(\mathrm{ml})^{\mathrm{a}}$ \\
\hline Celluclast 1.5L & 57 & 0.5 & 26.0 & 680 \\
Buzyme 2523 & 3 & 0.1 & 5.3 & 33 \\
\hline
\end{tabular}

${ }^{\text {a }}$ Enzymatic activity in the cocktails as provided by the suppliers.

${ }^{\mathrm{b}}$ Enzyme dosage used in the pulp treatments expressed per gram of ovendry (o.d.) pulp.

deinkability; (ii) the contribution of a pre-washing stage; (iii) the effect of attrition, caused by mixing the pulp, on the fragmentation and detachment of the printed ink films.

\subsection{Enzymes}

Two commercial enzymatic preparations were selected to perform this study: Celluclast 1.5L and Buzyme 2523. The first has been referred as an effective deinking aid [6,7,11]; the second was found to be efficient, in a preliminary set of assays [12], on the deinking of several paper pulps, namely a chemical pulp (MOW, $84 \%$ of ink removed), a mechanical pulp (51\%) and a photocopy printed pulp (92\%). The relevant hydrolytic activities of these preparations are presented in Table 1 . The endoglucanase, cellulase and xylanase activities were measured using the carboxymethylcellulase (CMCase), filter paper (FPase) and xylan oat spelt assays, respectively, as described in Wood and Bhat [13] and Bailey et al. [14].
Reducing sugars were measured by the dinitrosalicylic acid method (DNS), using glucose as standard [15].

\subsection{Paper pulp}

The pulp used in this work was kindly supplied by the paper company Renova, S.A. (Torres Novas, Portugal). It was obtained by disintegrating mixed office wastepaper (MOW) on the Renova mill, and provided as high consistency pulp slurry. In order to evaluate the pre-washing stage contribution to deinking, a preliminary washing step (as described in Section 2.5) was conducted immediately after the sample preparation: a "washed" mixed office wastepaper was obtained (WMOW).

\subsection{Enzymatic deinking}

The pulp ( $25 \mathrm{~g}$ on oven-dry basis) was suspended in distilled water and disintegrated for $10 \mathrm{~min}$ in a $250 \mathrm{ml}$ plastic container using a Heidolph overhead stirrer (model RZR-1) and a propeller especially designed for this work (Fig. 2). Then, the enzyme was added to the mixer according to the values shown in Table 1. The enzymatic preparations were previously diluted (in $10 \%$ of the total reaction volume), in order to achieve a better dispersion. According to the conditions defined in a previous work, the deinking reaction was allowed for $30 \mathrm{~min}$ at $11 \%$ consistency, $\mathrm{pH} 7.0$ and $50{ }^{\circ} \mathrm{C}$, with continuous slow mixing $[16,17]$. To inactivate the enzyme, the pulp suspension was boiled for $10 \mathrm{~min}$. The cellulose degradation was quantified using the DNS method. To avoid redeposition, the released ink was immediately separated from the fibres, as described ahead. The fibres were finally recovered for testing.

In order to test the effect of the mechanical action on enzymatic deinking some treatments occurred in the absence of mixing, after disintegrating the pulp for $1 \mathrm{~min}$; to evaluate the benefit of using surfactants during enzymatic deinking, Celluclast $1.5 \mathrm{~L}$ was supplemented with a commercial surfactant (Rhecol OCP_Allied Colloids) in other assays.

Control assays with denatured enzyme were made in parallel. Each experimental condition (enzymatic assay or control) was assayed twice and a good reproducibility was found. The
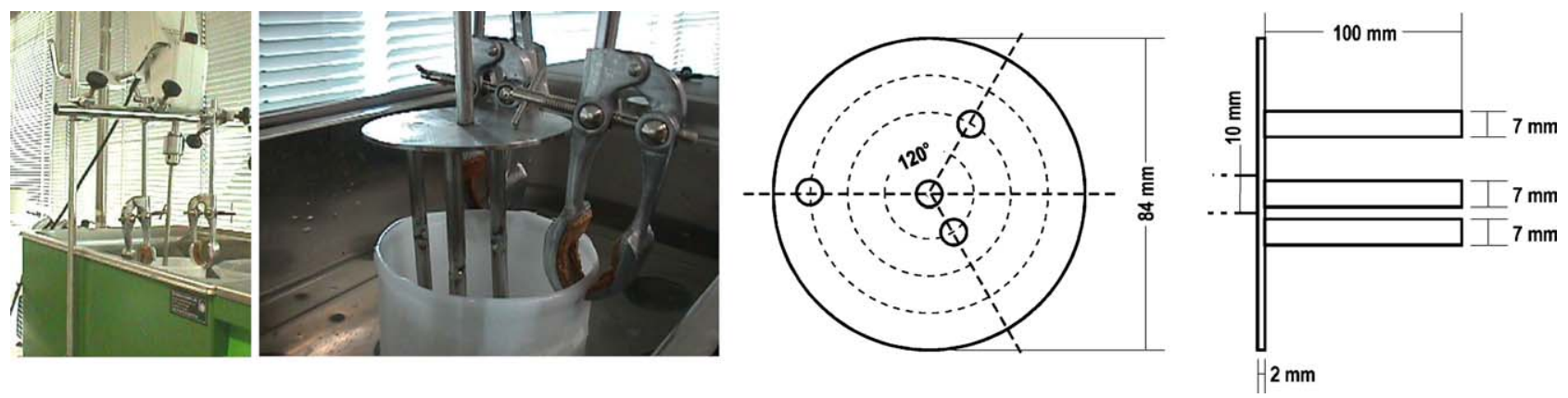

Fig. 2. Enzymatic/chemical treatment of pulp slurries at UM laboratory facilities (from the left to the right) pulp treatment device, propeller detail, propeller design. 
coefficients of variation of the determined physical properties and ink amount did never exceed $2 \%$ and $5 \%$, respectively.

\subsection{Chemical deinking}

Except for the final boiling, the chemical deinking assays were carried out as described above (Section 2.3); the effect of the mechanical action was also tested in this case. The concentration of chemical products was $2 \% \mathrm{NaOH}$ and $2 \%$ $\mathrm{Na}_{2} \mathrm{SiO}_{3}(\mathrm{w} / \mathrm{w})$; the final $\mathrm{pH}$ in the pulp suspension was 11.4.

Control assays were made with distilled water in the absence of chemicals. As for the enzymatic assays, each experimental condition was assayed twice with good reproducibility. The experimental conditions used were selected in a preliminary set of assays with different amounts of $\mathrm{NaOH}$, corresponding to $\mathrm{pH}$ values of 9.9, 10.4 and 11.0.

\subsection{Fibre/ink particle separation step}

According to results shown elsewhere, small ink particles present in MOW are best removed by washing [17]. MOW fibres were preferably washed with running tap water $(\approx 301)$ through a 200-mesh wire and then recovered for testing. In other assays, the pulps were floated in a laboratory flotation unit as described in Pala et al. [17].

\subsection{Deinking evaluation}

The physical and mechanical properties of the pulp and paper, and the amount of ink present in paper sheets, before and after the deinking treatment, were characterised as follows.

\subsubsection{Pulp and paper testing}

Handsheet preparation and determination of the pulp and paper properties followed the usual standard procedures: drainage rate (ISO 5267/1), handsheet preparation (ISO 5269/1), burst (ISO 2758), tensile (ISO 1924/2) and tear strength (ISO 1974).

\subsubsection{Image analysis}

The image analysis (IA) system is composed of a magnification lens (Olympus, model SZ-ST), illumination device (Olympus, model TL2), monochromatic CCD-camera (Sony, model AVC-DSCE), a CMA-D5CE adapter (Sony, Tokyo) and an image analysis interface DT-3152 (Marlboro, MA). The images were randomly acquired using the commercial software Image Pro Plus 3.0 (Media Cybermetrics, Silverspring). The same magnification and lightning were used throughout the work in order to obtain comparable results $[18,19]$. A $4 \times$ objective was chosen, as a reasonable compromise between image enlargement and analysed area. All handsheets were analysed from the same side (opposite to the mesh side). Particle counts, shapes and sizes were examined using commercially available software (Globalab Image 3.2, Data Translation, Marlboro). To ensure the reproducibility of the image analysis, a suitable threshold value was selected to identify the contaminants and that value was conserved throughout the work. For each $60 \mathrm{~g} / \mathrm{m}^{2}$ handsheet, 40 images were obtained and treated. The area analysed in each image of 438528 pixel was of about $13 \mathrm{~mm}^{2}$. The total area analysed in each handsheet was about $5.2 \mathrm{~cm}^{2}$. The dimension of the smallest detectable particle was $297 \mu \mathrm{m}^{2}$ (10 pixel), equivalent to a diameter of $19 \mu \mathrm{m}$, assuming a spherical geometry.

\section{Results and discussion}

\subsection{Chemical treatment}

As shown in Table 2, the chemical treatment increases the burst and tensile indexes, decreasing the tear index and the drainage rate. The extent of these modifications depends on the $\mathrm{pH}$, being lower for the higher $\mathrm{pH}$ values [20]. Sodium hydroxide affects the fibre swelling and conformability [21-23] and also the fibre/fibre attrition during the mechanical mixing of the pulps [24]. Swelling, which is at large extent responsible for the pulp and paper properties modification, depends on electrokinetic and osmotic effects [25-29]. For high $\mathrm{NaOH}$ concentrations, the ionic strength in the pulp suspension increases, reducing both the electrokinetic and osmotic effects, and in consequence, also the tensile and burst strengths; tear is not affected because it is not directly related to the number of interfibre bonds (determined by swelling). While acting on paper fibres (making them swell), $\mathrm{NaOH}$ contributes to ink removal as it favours the detachment and fragmentation of the adhered ink (based on Wielen et al. [10]). Additionally, it may also act directly on the printed ink film and weaken its structure, leading to fragmentation [1]. In samples as complex as MOW it is possible that the two mechanisms occur at the same time; however, the action of the chemical products is limited to the non-polymeric printed inks. According to the IA results, an effective ink removal is achieved by chemically treating the MOW pulps, especially when high dosages are used (Table 2). Moreover, the ink particle size distribution profiles indicate that the ink films are dislodged from the fibre surface as large particles, which are efficiently removed from the suspension during the flotation step (Fig. 3). In fact, the small particles amount is similar in all samples (treated and non-treated), while fewer large particles are present in the treated samples; this modification explains the median size decrease after the chemical treatment.

\subsection{Enzymatic deinking}

Table 2 also shows the results of MOW's enzymatic deinking with Celluclast. As discussed in a previous work [16], low enzyme dosages are recommended in order to preserve paper strength. The hydrolytic activity used ( $0.5 \mathrm{FPU} / \mathrm{g}$ o.d., which corresponds to $1-1.2 \%$ of fibres solubilisation) allowed the strength indexes maintenance and the drainage improvement. 
Table 2

Effect of the chemical/enzymatic deinking on the pulp and paper properties and ink particles characteristics (MOW)

\begin{tabular}{|c|c|c|c|c|c|c|c|c|}
\hline \multirow[t]{2}{*}{ Assayb $^{b}$} & \multicolumn{4}{|c|}{ Pulp and paper properties ${ }^{a}$} & \multicolumn{4}{|c|}{ Image analysis results } \\
\hline & $\mathrm{D}$ & Ts & $\mathrm{B}$ & $\mathrm{Te}$ & Ink area (ppm) & Efficiency $^{\mathrm{c}}(\%)$ & Particle count & Median size $(\mu \mathrm{m})$ \\
\hline \multicolumn{9}{|l|}{ Enzymatic deinking } \\
\hline Non-treated & 30 & 28.6 & 1.9 & 7.7 & 8507 & & 1774 & 1254 \\
\hline Control (F) & 42 & 36.2 & 2.5 & 8.1 & 7024 & & 1579 & 1194 \\
\hline Celluclast (F) & -7 & +1 & +4 & +1 & 6544 & 7 & 1670 & 1283 \\
\hline Control (W) & 20 & 26.4 & 1.8 & 8.3 & 4890 & & 640 & 1344 \\
\hline Celluclast (W) & +5 & +8 & +15 & +4 & 3428 & 30 & 571 & 1426 \\
\hline Control $(\mathrm{W}+\mathrm{S})$ & 20 & 27.5 & 1.8 & 8.2 & 4718 & & 672 & 1393 \\
\hline Celluclast $(\mathrm{W}+\mathrm{S})$ & 0 & 0 & +6 & 0 & 4288 & 9 & 603 & 1314 \\
\hline \multicolumn{9}{|l|}{ Chemical deinking } \\
\hline Non-treated & 34 & 37.7 & 2.5 & 9.2 & 10484 & & 1253 & 1283 \\
\hline Chemical (pH 9.9) & 47 & 44.2 & 2.9 & 8.4 & 4879 & n.d. & 1008 & 896 \\
\hline Chemical (pH 10.4) & 45 & 42.2 & 2.8 & 8.9 & 4545 & n.d. & 902 & 776 \\
\hline Chemical (pH 11.0) & 43 & 41.6 & 2.7 & 9.3 & 3621 & n.d. & 869 & 716 \\
\hline
\end{tabular}

${ }^{a}$ Physical properties in the enzymatic assays are expressed as \% relatively to the respective control: $\left(\mathrm{D},{ }^{\circ} \mathrm{SR}\right) \mathrm{drainage}$; $(\mathrm{Ts}, \mathrm{Nm} / \mathrm{g})$ tensile index; $\left(\mathrm{B},\left(\mathrm{kPam}{ }^{2} / \mathrm{g}\right)\right.$ burst index; $\left(\mathrm{Te},\left(\mathrm{mNm}^{2} / \mathrm{g}\right)\right.$ Tear index.

b Fibre/ink particle separation step: (F) flotation; (W) washing; $(+\mathrm{S})$ : with surfactant; in the chemical treatment, the fibres were separated from the ink particles by flotation; different "non-treated samples" correspond to different supplies of MOW.

c Deinking efficiency, expressed as \% of ink area reduction relatively to the control; (n.d.) not determined.

An ink removal of 7\% (for floated pulps) and 30\% (for washed pulps) was obtained. According to the IA results, Celluclast does not alter the ink particles distribution profile in MOW (not shown); washing is more effective than flotation in separating the ink particles from the enzymatically treated fibres, presumably because of the ink particles' median size in the samples [17]. Intensive enzymatic degradation leads to excessive fibrillation and ink fragmentation, which is undesirable $[5,6,11,30]$. Indeed, assays with higher enzymatic loads yield paper with poor properties without improving ink removal (data not shown). In another assay, this enzymatic preparation was complemented with a commercial surfactant (as in Jobbins and Franks [7] or Jeffries et al. [11]). The presence of surfactant does not favour deinking (only $9 \%$ - compared to $30 \%$ - without the surfactant, of the ink was removed when it was used); it is possible that either the type and/or the surfactant dosage were inadequately selected. In fact, the best enzyme/surfactant combination is difficult to estab-

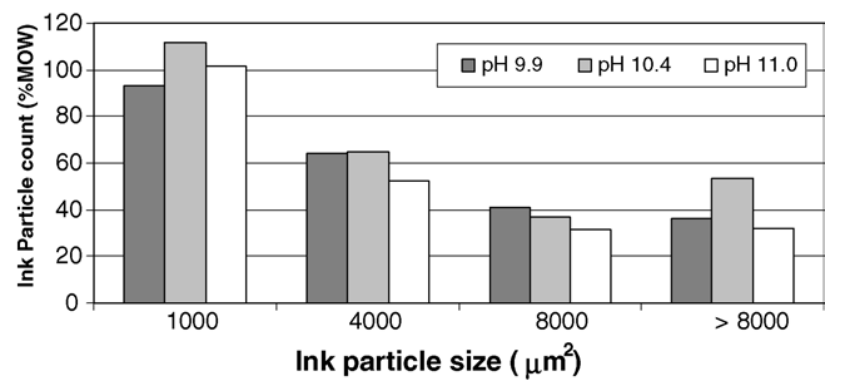

Fig. 3. Ink particle size distribution profiles after MOW chemical treatment. Particle count in the chemically treated samples expressed as \% relatively to the number of particles in the non-treated MOW. Considering an increasing size range, the ink particle count in MOW is 521, 522, 147 and 63, respectively. lish because it greatly depends on the deinking conditions ( $\mathrm{pH}$, mixing, temperature, consistency, period of operation) [7,11,31,32].

Different supplies of MOW were used in the chemical and enzymatic assays (Table 2). However, the comparison of the final ink content (ink area) for the more efficient conditions used in this work (Celluclast/W versus Chemical/pH 11.0) shows that the deinking effect is comparable. Regarding the physical properties of the paper supplies (non-treated samples), the quality of the one used in the chemical assays is superior. The improvement in paper strength appears to be more significant after the chemical treatment, an effect that is counterbalanced by the one in the drainage rate, which the enzymes quite improve (Celluclast/W and Chemical/pH 11.0 versus the respective non-treated samples).

In contrast with Celluclast, Buzyme diminishes all the strength indexes, a limitation in the use of this enzyme (Table 3). Moreover, the effectiveness of Buzyme to deink MOW is apparently lower than Celluclast's (19\% maximum efficiency versus $30 \%$, for non pre-washed pulps). The two enzymatic preparations present a different FPase:CMCase:Xylanase ratio (1:0.5:12 in Celluclast and 1:1.8:11 in Buzyme, Table 1), which may explain these results. Considering that Buzyme was applied to the fibres at a lower dosage ( 0.1 versus $0.5 \mathrm{FPU} / \mathrm{g}$ o.d. pulp), the endoglucanolytic activity seems to be quite critical to the manipulation of this pulp. However, no direct relationship should be established between the enzymes activity and the deinking efficiency. Other effects must be considered, namely the properties of the enzymes (processitivity, adsorption, etc.), the presence of non-identified (synergistic) secondary activities [16] and the presence of chemical products in the commercial enzymatic preparations that interfere with the deinking process [17]. 


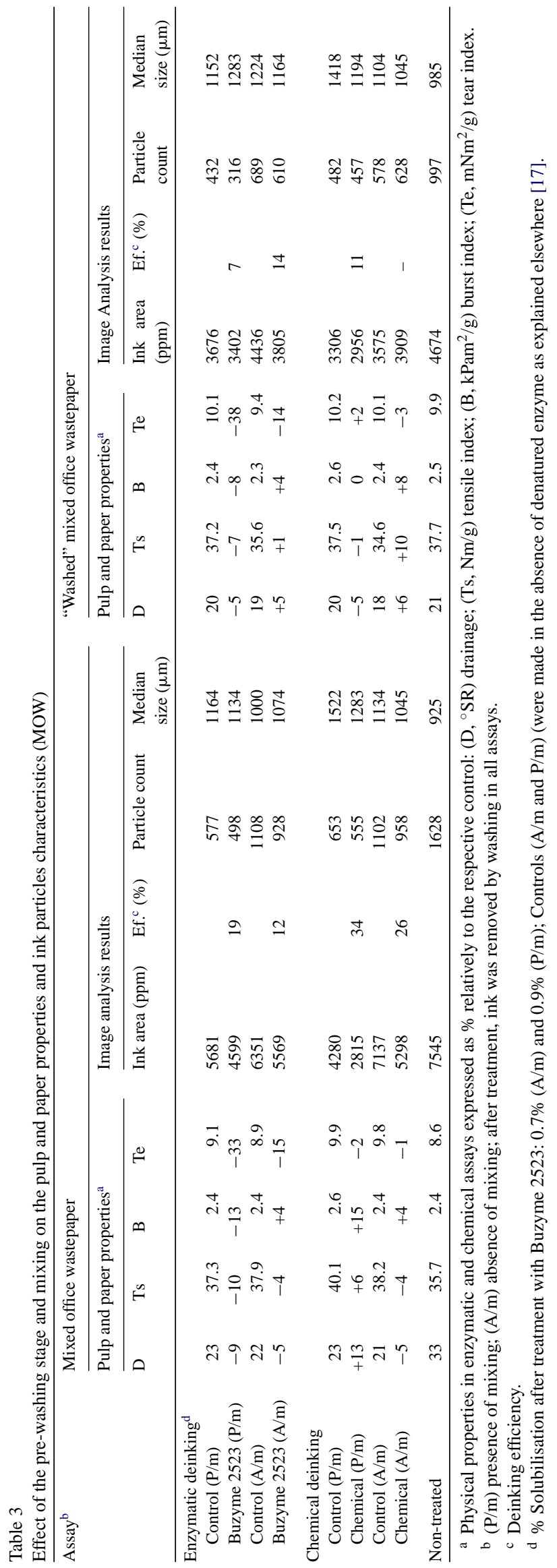

\subsection{Contribution of a pre-washing step and mixing}

Pre-washing the pulps before chemically or enzymatically treating the fibres, and mixing during treatment, also influences deinking (Table 3). When MOW is washed immediately after paper disintegration, about $38 \%$ of the initial ink is removed (non-treated sample: washed versus non-washed MOW), without changing the ink particle profiles of the two samples (data not shown). In addition to ink removal, a significant improvement of the pulp and paper physical properties is detected, which is probably due to the removal of fillers and fines [17]. These modifications may render the fibres less difficult to deink, because the dislodged ink particles redeposition on the fibres surface and its penetration in the porous structure of the fibres is avoided [5,6,33], and also because, in the absence of additives, the fibres become more accessible/susceptible to the deinking aids action. In fact, when pulps are pre-cleaned, lower residual ink values are obtained after treatment (Table 3). Moreover, exception made for the Chemical $\mathrm{P} / \mathrm{m}$ assays, the fibres generally tend to develop better strength properties during the enzymatic/chemical treatments (controls versus assays, in MOW and WMOW).

Mixing favours mass transfer and promotes fibre erosion. Therefore, the lower strength loss (Buzyme, MOW and WMOW) and the lower strength restore (chemical products, MOW) in the $\mathrm{A} / \mathrm{m}$ paper-sheets (control versus assays, Table 3) may be explained by a deficient dispersion of the deinking aids on the pulp suspension, which limits the hydrolytic activity $(0.7 \%$ solubilisation versus $0.9 \%)$ and the chemical products effect on the fibres. In the case of the enzymatic treatments, the fibres surface may also suffer excessive erosion by the combined hydrolytic and mechanical actions; the severe fibrillation mechanism turns the fibre structure more vulnerable and affects the bonding potential and collapsibility of the fibres. In fact, when mixing was used during the enzymatic treatment more permeable sheets were obtained: MOW (2242 $\mathrm{ml} / \mathrm{min}$ versus $1863 \mathrm{ml} / \mathrm{min})$; WMOW (2384 $\mathrm{ml} / \mathrm{min}$ versus $2092 \mathrm{ml} / \mathrm{min})$.

Excessive fibre erosion may also be related to the combined action of mixing and chemical treatment; that may explain the lower strength gain in the mixed-WMOW (as compared with the one in the mixed-MOW). It is clearly shown that mixing is favourable to the ink removal, especially when a large amount of contaminants is present in the pulps. Indeed, lower residual ink area values and ink particle counts are detected in the mixed MOW and WMOW samples. The simultaneous mixing/deinking aids action favours the removal of the strongly adhered polymeric inks present in office-wastepaper. In fact, the lower ink particles median size in the $\mathrm{A} / \mathrm{m}$ chemically treated samples (relatively to the $\mathrm{P} / \mathrm{m}$ 's) indicates that in the absence of mixing the smaller particles stay adhered to the fibres and are not removed. Considering this synergistic effect, some authors suggest the use of deinking aids immediately at the beginning of the paper recycling cycle [5-7,31,33-37]. However, it is important to remark that the effectiveness of mixing on the ink particle 
removal depends on the mixing conditions [38,39] and different conditions (e.g. period and intensity of mixing) may lead to different results.

\section{Conclusions}

Enzymes can be deinking aids as effective as chemicals, although the results depend on the type of enzymatic preparation used. The hydrolytic activity is frequently associated to a reduction on the paper mechanical properties. However, in the current case, an improvement in tensile, burst and tear indexes was found. Comparing with the chemically treated pulps, these strength indexes are lower but, on the other hand, the enzymatically treated pulp drainability is better. Balancing these effects, enzymatic deinking is an alternative to the intensive use of chemical products in the conventional process, especially if the lower environmental impact of enzymatic deinking is taken into account.

\section{Acknowledgement}

The authors gratefully thank the paper company Portucel Viana for the use of laboratory facilities.

\section{References}

[1] Shrinath A, Szewczak JT, Bowen IJ. A review of ink-removal techniques in current deinking technology. Tappi J 1991;74(7):8593.

[2] Heise OU, Unwin JP, Klungness JH, Fineran Jr WG, Sykes M, Abubakr S. Industrial scaleup of enzyme-enhanced deinking of nonimpact printed toners. Tappi J 1996;79(3):207-12.

[3] Knudsen O, Young JD, Yang JL. Long-term use of enzymatic deinking at Stora Dalum plant. In: Seventh International Conference Biotech. Pulp Paper Industry. 1998. p. A17-20.

[4] Bajpai P, Bajpai PK. Deinking with enzymes: a review. Tappi J 1998;81(12):111-7.

[5] Kim T-J, Ow SS-K, Eom T-J. Enzymatic deinking method of wastepaper. In: TAPPI Pulping Conference Proceedings. 1991. p. 1023-31.

[6] Jeffries TW, Klungness JH, Sykes MS, Rutledge-Cropsey K. Comparison of enzyme-enhanced with conventional deinking of xerographic and laser-printed paper. Tappi J 1994;77(4):1739.

[7] Jobbins JM, Franks NE. Enzymatic deinking of mixed office waste: process condition optimization. Tappi J 1997;80(9):73-8.

[8] Johnson DA, Thompson EV. Fiber and toner detachment during repulping of mixed office waste containing photocopied and laserprinted paper. Tappi J 1995;78(2):41-6.

[9] Kakogiannos A, Johnson DA, Thompson EV. Laboratory highconsistency dispersion studies of laser-printed office copy paper, Part II. Tappi J 1998;81(4):159-65.

[10] Wielen LCV, Panek JC, Pfromm PH. Fracture of toner due to paper swelling. Tappi J 1999;82(5):115-21.

[11] Jeffries TW, Sykes MS, Rutledge-Cropsey K, Klungness JH, Abubakr S. Enhanced removal of toners from office waste papers by microbial cellulases. In: Sixth International Conference Biotech. Pulp Paper Industry. 1995. p. 141-4.
[12] Pala H, Gama FM, Mota M. Preliminary studies on enzymatic deinking. In: Seventh International Conference Biotech. Pulp Paper Industry. 1998. p. C189-92.

[13] Wood TM, Bhat KM. Methods for measuring cellulase activities. Methods Enzymol 1988;160(9):87-112.

[14] Bailey MJ, Biely P, Poutanen K. Interlaboratory testing of methods for assay of xylanase activity. J Biotechnol 1992;23:257-70.

[15] Bernfeld P. Amylases, $\alpha$ and $\beta$. Methods Enzymol 1955;1(17):149-52.

[16] Pala H, Lemos MA, Mota M, Gama FM. Enzymatic upgrade of old paperboard containers. Enzyme Microb Technol 2001;29: 274-9.

[17] Pala H, Mota M, Gama FM. Enzymatic versus chemical deinking of non-impact ink printed paper. J Biotechnol 2004;108(1):79-89.

[18] Zeyer C, Venditti RA, Puangchinda KW, Heitmann JA. The distribution of impurities in pulp and paper: the effects of the random distribution of impurities on image analysis. Tappi J 1995;78(2): 168-75.

[19] Zeyer C, Venditti RA, Heitmann JA. The effect of sample size on the confidence interval for image analysis of impurities in pulp and paper. Tappi J 1995;78(2):176-9.

[20] Pala, H. Utilizasão de Xilanases e de Celulases na Reciclagem de Fibras de Papel. PhD Thesis. Escola de Engenharia da Universidade do Minho 2002.

[21] Bhat GR, Heitmann JA, Joyce TW. Novel techniques for enhancing the strength of secondary fibre. Tappi J 1991;74(9):151-7.

[22] Marton R, Brown A, Granzow S, Koeppicus R, Tomlinson S. Recycling and fibre structure. Prog Paper Recycl 1993;3(2):58-70.

[23] Chen Z-X, Heitmann JA, Chang H-M. Secondary fibre quality enhancement-alkaline and oxygen treatment. Paper Technol 1998;40(9):45-9.

[24] Azevedo MAD, Drelich J, Miller JD. The effect of pH on pulping and flotation of mixed office wastepaper. J Pulp Paper Sci 1999;25(9):317-20.

[25] Scallan AM, Grignon J. The effect of cations on pulp and paper properties. Svensk Papperstidning 1979;82(2):40-7.

[26] Grignon J, Scallan AM. The effect of $\mathrm{pH}$ and neutral salts upon the swelling of cellulose gels. J App Polym Sci 1980;25:282943.

[27] Katz S, Liebergott N, Scallan AM. A mechanism for the alkali strengthening of mechanical pulps. Tappi 1981;64(7):97-100.

[28] Lindstrom T, Carlsson G. The effect of chemical environmental on fiber swelling. Svensk Papperstidning 1982;85(3):R14-20.

[29] Scallan AM. The effect of acidic groups on the swelling of pulps: a review. Tappi J 1983;66(11):73-5.

[30] Treimanis A, Leite M, Eisimonte M, Viesturs U. Enzymatic deinking of laser-printed white office wastepaper. Chem Biochem Eng 1999;13(2):53-7.

[31] Sykes M. Enzymatic deinking of sorted mixed office waste: recommendations for scale-up. In: Sixth International Conference Biotech. Pulp Paper Industry. 1995.

[32] Kaya F, Heitmann Jr JA, Joyce TW. Influence of surfactants on the enzymatic hydrolysis of xylan and cellulose. Tappi J 1995;78(10):150-7.

[33] Zeyer C, Joyce TW, Heitmann JA, Rucker JW. Performance study of enzymatic deinking using cellulase/hemicellulase blends. In: Sixth International Conference Biotech. Pulp Paper Industry. 1995. p. 169-72.

[34] Prasad DY. Enzymatic deinking of laser and xerographic office wastes. Appita 1993;46(4):289-92.

[35] Jeffries TW, Klungness JH, Sykes MS, Rutiedge-Cropsey K. Preliminary results of enzyme-enhanced versus conventional deinking of xerographic printed paper. In: TAPPI Rec. Symposium Notes. 1993. p. $183-8$.

[36] Zeyer C, Joyce TW, Heitmann JA, Rucker JW. Factors influencing enzyme deinking of recycled fiber. Tappi J 1994;77(10):16977. 
[37] Bennington CPJ, Sui OS, Smith JD. The effect of mechanical action on waste paper defibering and ink removal in repulping operations. J Pulp Paper Sci 1998;24(11):341-8.

[38] Putz H-J, Göttsching L, Renner K, Jokinen O. Enzymatic deinking in comparison with conventional deinking of offset news. In: TAPPI Pulping Conference Proceedings. 1994. p. 87784.

[39] Ackermann C, Putz H-J, Göttsching L. Effect of pulping conditions on deinking of wood-containing recovered paper grades. Pulp Paper Can 1999;100(4):37-41. 